\title{
Wetting and Interfacial Chemistry of SnZnCu Alloys with Cu and Al Substrates
}

\author{
Przemysław Fima, Janusz Pstruś, and Tomasz Gancarz
}

\author{
(Submitted August 26, 2013; in revised form November 29, 2013; published online January 29, 2014)
}

\begin{abstract}
Wetting of $\mathrm{Cu}$ and $\mathrm{Al}$ pads by $\mathrm{Sn}-\mathrm{Zn}$ eutectic-based alloys with $0.5,1$, and 1.5 wt.\% of $\mathrm{Cu}$ was studied at $250{ }^{\circ} \mathrm{C}$, in the presence of $\mathrm{ALU} 33 \AA$ flux, with wetting times of $15,30,60$, and $180 \mathrm{~s}$, respectively. With increasing wetting time the wetting angle decreases only slightly and the angles on $\mathrm{Cu}$ pads are higher than those on Al pads. Selected, solidified solder-pad couples were cross-sectioned and subjected to SEM-EDS study of the interfacial microstructure. The results revealed that the microstructure of the $\mathrm{SnZnCu} / \mathrm{Cu}$ interface is much different from $\mathrm{SnZnCu} / \mathrm{Al}$ interface. In the first case continuous interlayers are observed while in the latter case there is no interlayer but the alloy dissolves the substrate along grain boundaries.
\end{abstract}

Keywords microstructure, $\mathrm{Sn}-\mathrm{Zn}-\mathrm{Cu}$, wetting

\section{Introduction}

Among Pb-free solders $\mathrm{Sn}-9 \mathrm{Zn}$ (wt.\%) solder alloy is considered the best with respect to cost per mass unit. Also, its melting temperature $\left(199{ }^{\circ} \mathrm{C}\right)$ makes it a close match to conventional $\mathrm{Sn}-37 \mathrm{~Pb}$ solder. Mechanical and thermal properties of $\mathrm{Sn}-\mathrm{Zn}$ solder alloys and wetting behavior on $\mathrm{Cu}$ were thoroughly studied by numerous authors, in particular good mechanical properties were reported but the wettability was inferior to $\mathrm{Sn}-37 \mathrm{~Pb}$ (Ref 1, 2). Some researchers studied corrosion behavior of Sn-Zn alloys in gaseous mixtures (Ref 3) and high-humidity conditions (Ref 2) and found $\mathrm{Sn}-\mathrm{Zn}$ alloys prone to corrosion. In order to improve corrosion resistance and wetting properties alloying additions were introduced including for example: $\mathrm{Ag}(\operatorname{Ref} 4,5), \mathrm{Bi}(\operatorname{Ref} 2,6), \mathrm{Cu}(\operatorname{Ref} 7)$, and In (Ref 8). The results of some of these efforts were reviewed by Zhang and co-workers (Ref 9). Despite intensive development of new joining techniques such as ultrasonic-assisted joining (Ref 10), Sn-Zn-based solders were found to be useful in joining of aluminum with dissimilar materials, in particular copper (Ref 11).

$\mathrm{Yu}$ et al. (Ref 12) were among the first to study wetting properties and interfacial microstructure of $\mathrm{Sn}-9 \mathrm{Zn}-x \mathrm{Cu}$ solders $(x=0,2,4,6$, and 10 wt. $\%)$ and $\mathrm{Cu}$ substrate. Based on reflow

This article is an invited submission to JMEP selected from presentations at the Symposia "Wetting," "Interface Design," and "Joining Technologies" belonging to the Topic "Joining and Interface Design" at the European Congress and Exhibition on Advanced Materials and Processes (EUROMAT 2013), held on September 8-13, 2013, in Sevilla, Spain, and has been expanded from the original presentation.

Przemysław Fima, Janusz Pstruś, and Tomasz Gancarz, Institute of Metallurgy and Materials Science, Polish Academy of Sciences, ul. Reymonta 25, 30-059 Kraków, Poland. Contact e-mail: p.fima@ imim.pl. test with peak temperature $260{ }^{\circ} \mathrm{C}$, they found that increased copper content ( $2 \mathrm{wt} . \%$ and more) improves wetting and increases $\mathrm{Cu}_{6} \mathrm{Sn}_{5}$ IMC in the interlayer on expense of the $\mathrm{Cu}_{5} \mathrm{Zn}_{8}$. The $\gamma-\mathrm{Cu}_{5} \mathrm{Zn}_{8}$ phase is the only one that they found at the eutectic $\mathrm{Sn}-\mathrm{Zn} / \mathrm{Cu}$ interface. Chou et al. (Ref 7) studied interaction between $\mathrm{Sn}-9 \mathrm{Zn}-x \mathrm{Cu}$ alloys $(x=0,1$, and $10 \mathrm{wt} . \%)$ and $\mathrm{Cu}$ substrate at $250{ }^{\circ} \mathrm{C}$ with reaction time of several hours, and they found up to three intermetallic (IMC) layers at the interface: $\varepsilon-\mathrm{CuZn}_{5}, \gamma-\mathrm{Cu}_{5} \mathrm{Zn}_{8}$, and $\beta-\mathrm{CuZn}$. IMCs layer growth is observed in the case of all $\mathrm{Sn}-\mathrm{Zn}-x \mathrm{Cu}$ solders on $\mathrm{Cu}$ with $\gamma$ $\mathrm{Cu}_{5} \mathrm{Zn}_{8}$ being the dominant one, yet as pointed in (Ref 7) the literature data on remaining IMCs are inconclusive. What is particularly interesting is the early stage of IMC layer growth i.e., occurring in the first seconds of wetting, as this should help explain the order in which IMCs are grown. To study this is not easy, as it requires to hold a sample at high temperature for specified time and then to cool it rapidly below solidus temperature of solder to preserve the interfacial microstructure. In this work we attempt to study evolution of the interface between liquid $\mathrm{Sn}-\mathrm{Zn}-x \mathrm{Cu}(x=0.5,1.0$, and $1.5 \mathrm{wt} . \%)$ solders and $\mathrm{Cu}$ substrate held at $250{ }^{\circ} \mathrm{C}$ for a short time of $15,30,60$, and $180 \mathrm{~s}$. Also, to the best of the present authors knowledge there are no reports in the available literature on the wetting and interfacial microstructure of $\mathrm{Sn}-\mathrm{Zn}-\mathrm{Cu} / \mathrm{Al}$ couples. Therefore, the aim of this work is to study the effect of time on microstructure evolution of the interfaces $\mathrm{Sn}-\mathrm{Zn}-\mathrm{Cu} / \mathrm{Cu}$ and $\mathrm{Sn}-$ $\mathrm{Zn}-\mathrm{Cu} / \mathrm{Al}$

\section{Materials and Method}

Three alloys based on Sn-8.8Zn (eutectic) containing small addition of copper: $0.5,1.0$, and 1.5 wt. $\%$, respectively, were used for a study of wetting on $\mathrm{Cu}(99.9 \%)$ and $\mathrm{Al}(99.5 \%)$ substrates with the sessile drop method (SD). Solders were prepared by melting pure metals $(99.999 \%)$ in graphite crucibles, under $\operatorname{Ar}(99.9992 \%)$ protective atmosphere to avoid oxidation. The as-cast alloys were cut into suitable pieces of approximately $0.2 \mathrm{~g}$ and degreased with acetone prior the tests. Except for degreasing, there was no special treatment of 
substrates $(25 \times 20 \times 0.2 \mathrm{~mm})$. The wetting tests were carried out at $250{ }^{\circ} \mathrm{C}$ on aluminum and copper substrates, for 15,30 , 60 , and $180 \mathrm{~s}$, respectively, with the setup earlier used in studies of Sn-Zn-X alloys (Ref 13). The advantage of the setup is that it enables quick transfer of the sample to the already heated furnace, so the heating rate is very fast, as well as the sample is quickly transferred out after the designated time of the test.

Wetting tests were performed with ALU33 $^{\circledR}$ flux ( $\sim 0.05 \mathrm{~cm}^{3}$ ) applied to the solder sample and the surrounding part of the substrate. According to ISO 9454-1 this is the 2.1.2type flux i.e., organic, water-soluble, and activated with halides. Its components are aminoethylethanolamine $\left(\mathrm{C}_{4} \mathrm{H}_{12} \mathrm{~N}_{2} \mathrm{O}\right)$ and ammonium fluoroborate $\left(\mathrm{NH}_{4} \mathrm{BF}_{4}\right)$. The reported wetting angles are the average of three independent measurements on solidified samples after washing flux residue with tap water. After wetting tests, the selected solidified solder/substrate couples were cut perpendicular to the plane of the interface, mounted in conductive resin, and polished for microstructural characterization. The microstructural and energy-dispersive spectroscopy (EDS) analysis was performed with Quanta 3D FEG system, at $20 \mathrm{kV}$, with the use of the standardless Analysis EDAX System based on Genesis 4000 software.

\section{Results and Discussion}

\subsection{Cu Substrate}

The results of wetting angle measurements on $\mathrm{Cu}$ substrates are shown in Fig. 1; one could see that for all the investigated solder/substrate pairs the effect of time on wetting angle is negligible. Wetting angles of $\mathrm{Sn}-\mathrm{Zn}-\mathrm{Cu}$ alloys on $\mathrm{Cu}$ are generally lower than the wetting angles of $\mathrm{Sn}-\mathrm{Zn}$ on $\mathrm{Cu}$. On the other hand, the results of different $\mathrm{Sn}-\mathrm{Zn}-\mathrm{Cu}$ alloys on $\mathrm{Cu}$ are within the experimental error, which is particularly well seen after $180 \mathrm{~s}$ of wetting. The present wetting angle data for Sn$\mathrm{Zn}-x \mathrm{Cu}$ alloys are significantly lower than the data of (Ref 12) for alloys of similar composition. Similarly, different fluxes used in the present study are most likely the reason why wetting angles of $\mathrm{Sn}-8.8 \mathrm{Zn}$ alloy are lower than the angle of the same alloy on the same type of substrate reported earlier (Ref 13). Such a difference is an indication that deoxidation of metallic surfaces by the flux used earlier (Ref 13) is not sufficient.

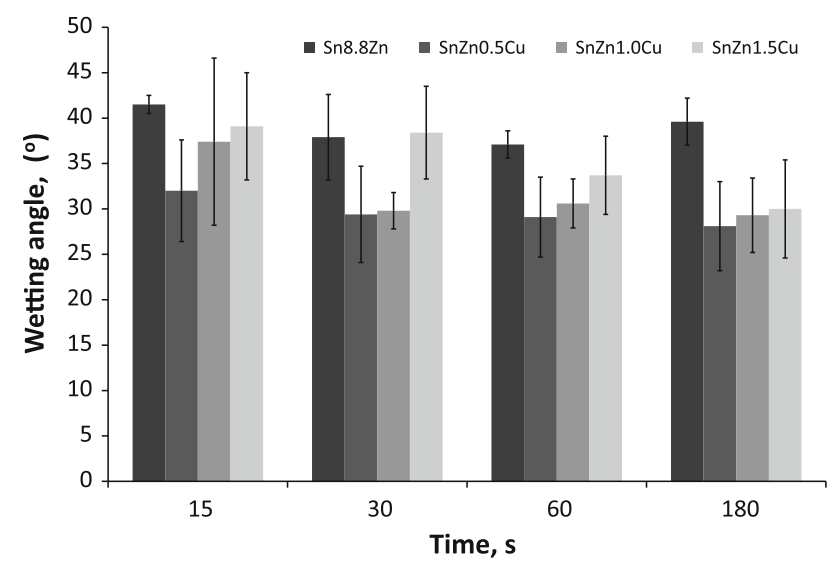

Fig. 1 Wetting angle of Sn-Zn- $x \mathrm{Cu}$ alloys on $\mathrm{Cu}$ pads, $x=0.5,1.0$, and $1.5 \mathrm{wt} . \%$
Figure 2 illustrates the interfacial microstructure of Sn-Zn$1.0 \mathrm{Cu} / \mathrm{Cu}$ couples after $15,30,60$, and $180 \mathrm{~s}$ of wetting, respectively. Similar results were obtained for $x=0.5 \mathrm{wt} . \% \mathrm{Cu}$ and $x=1.5 \mathrm{wt} . \% \mathrm{Cu}$. One could see that with increasing time of wetting the observed number and thickness of interlayers (formed of reaction products between liquid alloy and solid substrate) varies. More on reactive wetting can be found in review (Ref 14). Although there are a few intermetallic phases in the sub-binaries of $\mathrm{Sn}-\mathrm{Zn}-\mathrm{Cu}$ (namely: $\mathrm{CuZn}_{4}, \mathrm{CuZn}$, $\mathrm{Cu}_{5} \mathrm{Zn}_{8}, \mathrm{CuSn}_{3}$, and $\mathrm{Cu}_{6} \mathrm{Sn}_{5}$ ), regarding the $\mathrm{Sn}-\mathrm{Zn} / \mathrm{Cu}$ interface $\mathrm{Zn}$ has stronger than $\mathrm{Sn}$ affinity for $\mathrm{Cu}$, the $\mathrm{Cu}_{5} \mathrm{Zn}_{8}$ has the lowest Gibbs free energy of formation (Ref 15) and also low activation energy of growth (Ref 16). As shown in Fig. 2, there is a certain difference between the interfaces after $15,30 \mathrm{~s}$ and the interfaces after $60,180 \mathrm{~s}$ of wetting. In the first case (wetting time up to $30 \mathrm{~s}$ ) a single interlayer can be observed. According to EDS analysis results collected in Table 1 its composition is close to $\varepsilon-\mathrm{CuZn}_{4}$ phase assuming that $\mathrm{Sn}$ substitutes portion of $\mathrm{Zn}$. In the second case (wetting time $60 \mathrm{~s}$ and more) there are two distinct interlayers. The upper layer is clearly scalloped from the side of the solder and according to EDS (Table 1) its composition is close to $\mathrm{CuZn}_{4}$ phase. The thickness of the layer adjacent to the substrate is greater and increases with time of wetting. Its composition determined with EDS matches $\mathrm{Cu}_{5} \mathrm{Zn}_{8}$, although some content of $\mathrm{Sn}$ is observed. This phase is flat on both sides and is known to be a barrier for diffusion of Sn toward substrate thus preventing formation of $\mathrm{Cu}_{6} \mathrm{Sn}_{5}$. Since it is prone to fractures which enable diffusion of $\mathrm{Sn}$, its growth should be controlled. According to thermodynamic calculations ( $\operatorname{Ref} 17) \mathrm{Cu}_{5} \mathrm{Zn}_{8}$ is the phase that should form first, i.e., before $\mathrm{CuZn}_{4}$, at the $\mathrm{Sn} 8.8 \mathrm{Zn} / \mathrm{Cu}$ interface, however present results after 15 and $30 \mathrm{~s}$ of wetting do not confirm this. According to the present results, the $\varepsilon$ $\mathrm{CuZn}_{4}$ phase is the first that is formed at the interface and the $\gamma$ $\mathrm{Cu}_{5} \mathrm{Zn}_{8}$ appears after $60 \mathrm{~s}$ of wetting and grows faster than the $\varepsilon-\mathrm{CuZn} n_{4}$. It can be speculated that $\gamma-\mathrm{Cu}_{5} \mathrm{Zn}_{8}$ is formed as a result of copper diffusion from solid substrate to $\varepsilon-\mathrm{CuZn}_{4}$ and subsequent nucleation and crystallization within the $\varepsilon-\mathrm{CuZn}_{4}$, as in the micrograph (Fig. 3) showing particles of $\varepsilon-\mathrm{CuZn}_{4}$ in the matrix of $\mathrm{Sn}-\mathrm{Zn}-1.5 \mathrm{Cu}$ solder after $180 \mathrm{~s}$ at $250{ }^{\circ} \mathrm{C}$ with grains of $\gamma-\mathrm{Cu}_{5} \mathrm{Zn}_{8}$ inside. Figure 4 shows the $\mathrm{Sn}-\mathrm{Zn}-1.0 \mathrm{Cu} / \mathrm{Cu}$ couple after $180 \mathrm{~s}$ at $250{ }^{\circ} \mathrm{C}$ with the line indicating the position of the original interface at the beginning of wetting. The fact that the thickness of intermetallic layer from the side of solder is approximately the same as thickness from the side of substrate suggests that diffusion of $\mathrm{Cu}$ from substrate into $\gamma$ $\mathrm{Cu}_{5} \mathrm{Zn}_{8}$ is similar to that of $\mathrm{Zn}$ from the solder.

Generally, if there is more than one intermetallic formed at the interface, the intermetallic in direct contact with liquid at the triple line determines wetting (Ref 18). The fact that wetting angles (Fig. 1) after 15 and $180 \mathrm{~s}$ are close means that intermetallic in contact with liquid is the same after 15 and $180 \mathrm{~s}$, which is in agreement with EDS results (Table 1). Thickness of the intermetallic layers in Fig. 2 was measured at 10 spots at least at two separate micrographs per each solder/ substrate couple with Axio Vision and later averaged. It has to be noted that for wetting times 15 and $30 \mathrm{~s}$ the intermediate layer is thin, as can be seen in Fig. 2(a), (b), with EDS analysis we found its composition to be close to $\mathrm{CuZn}_{4}$. For this reason in Fig. 5 there is only one data bar at 15 and $30 \mathrm{~s}$, while for 60 and $180 \mathrm{~s}$ the two data bars represent thickness of $\mathrm{CuZn}_{4}$ and $\mathrm{Cu}_{5} \mathrm{Zn}_{8}$ layers. After 15, $30 \mathrm{~s}$ the thickness of intermetallic layer is similar. Starting from $60 \mathrm{~s}$, with increasing time of 

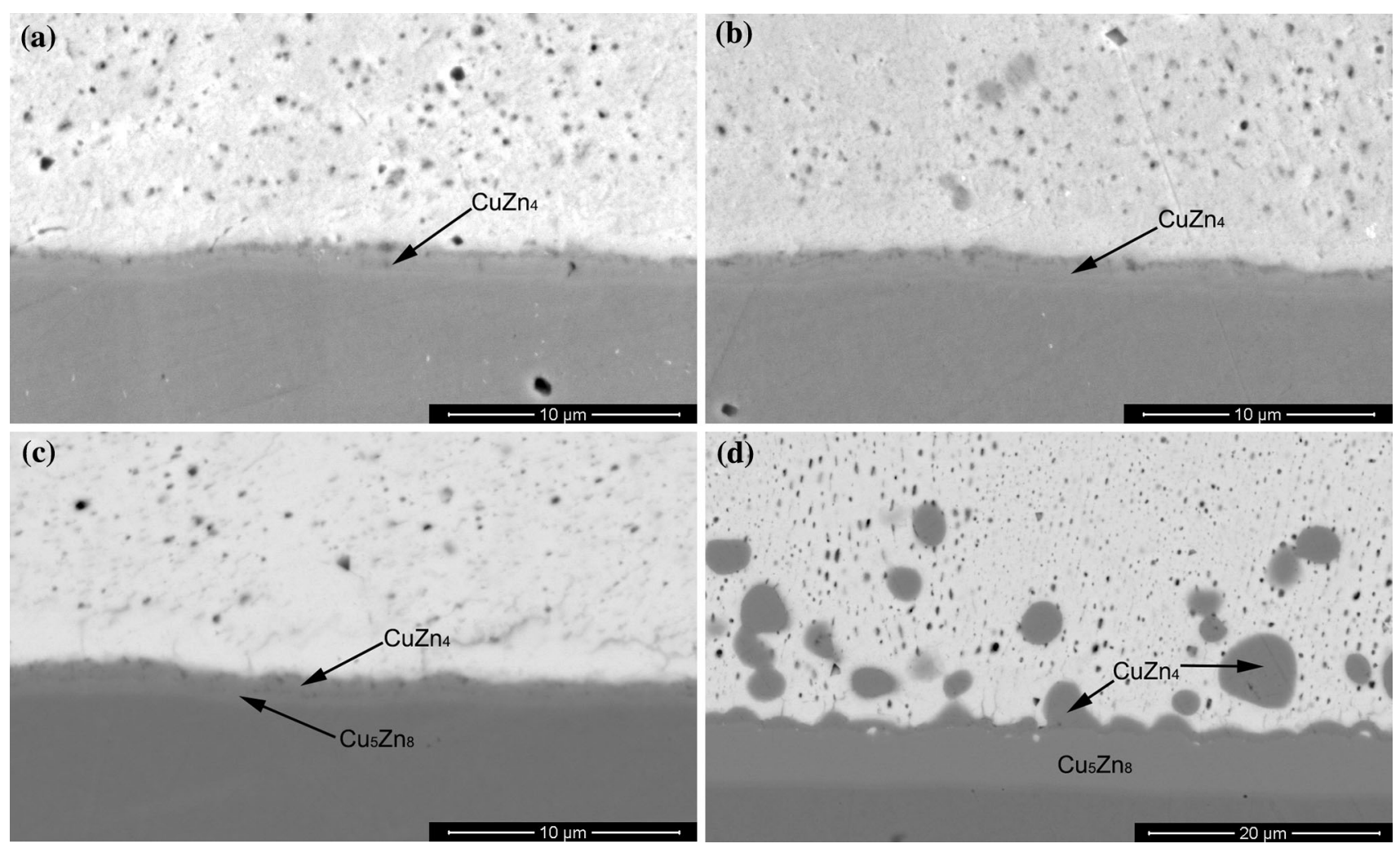

Fig. 2 Interfacial microstructure of Sn-Zn-1.0Cu/Cu couples, (a) $15 \mathrm{~s}$, (b) $30 \mathrm{~s}$, (c) $60 \mathrm{~s}$, and (d) $180 \mathrm{~s}$

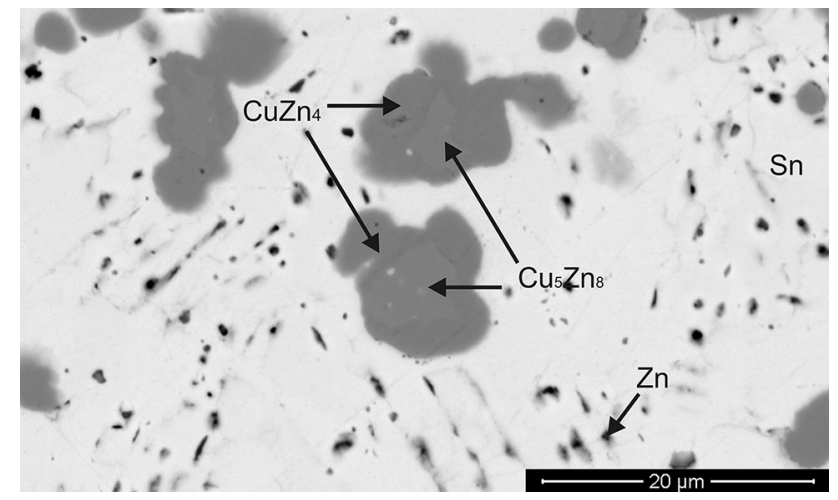

Fig. $3 \varepsilon-\mathrm{CuZn}_{4}$ precipitate in $\mathrm{Sn}-\mathrm{Zn}-1.5 \mathrm{Cu}$ solder matrix with $\gamma$ $\mathrm{Cu}_{5} \mathrm{Zn}_{8}$ nucleated inside

wetting thickness of $\mathrm{Cu}_{5} \mathrm{Zn}_{8}$ layers significantly increases as shown in Fig. 5, whereas thickness of $\mathrm{CuZn}_{4}$ remains small. Similar results were obtained for $x=0.5 \mathrm{wt} . \% \mathrm{Cu}$ and $x=1.5$ wt. $\% \mathrm{Cu}$.

Based on the present experimental results the following order of events at the interface of liquid $\mathrm{Sn}-\mathrm{Zn}-x \mathrm{Cu}(x$ up to 1.5 wt.\%) with $\mathrm{Cu}$ substrate is proposed. Initially, liquid $\mathrm{Zn}$ from the solder reacts with $\mathrm{Cu}$ dissolved from solid substrate and thin $\mathrm{CuZn}_{4}$ layer is formed (Fig. 6a). The most likely reason that it is $\mathrm{CuZn}_{4}$ rather than $\mathrm{Cu}_{5} \mathrm{Zn}_{8}$ is that the influx of $\mathrm{Zn}$ toward substrate exceeds the dissolution rate of $\mathrm{Cu}$. Therefore, each $\mathrm{Cu}$ atom is instantly consumed as the fresh $\mathrm{Zn}$ atoms are coming from the bulk of the solder. Next (Fig. 6b), $\mathrm{Zn}$ diffuses through the $\mathrm{CuZn}_{4}$ toward substrate (at

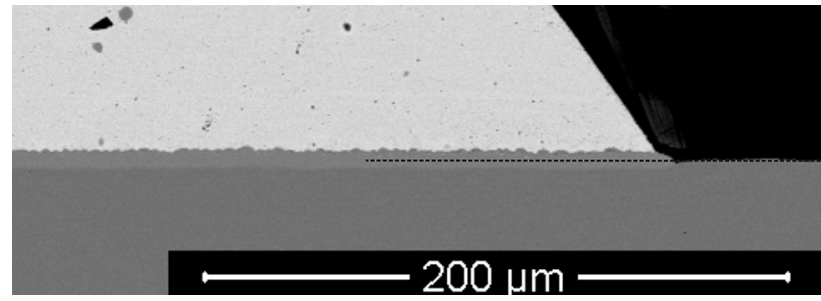

Fig. $4 \mathrm{Sn}-\mathrm{Zn}-1.0 \mathrm{Cu} / \mathrm{Cu}$ interface after $180 \mathrm{~s}$ of wetting at $250{ }^{\circ} \mathrm{C}$. Dashed line indicates the position of the original interface

the same time $\mathrm{Cu}$ diffuses the other way) and the $\mathrm{Cu}_{5} \mathrm{Zn}_{8}$ is formed adjacent to the substrate. Because of diffusion of $\mathrm{Zn}$ from the solder the $\mathrm{Cu}_{5} \mathrm{Zn}_{8}$ keeps growing and its growth is faster than the $\mathrm{CuZn}_{4}$ as the system tends to reach the minimum energy (Fig. 6c).

In the case of alloys containing 1.0 and 1.5 wt. $\% \mathrm{Cu}$ after $180 \mathrm{~s}$ of wetting, isolated precipitates of $\mathrm{CuZn}_{4}$ phase are present in the solder particularly numerous in the vicinity of the interface. According to Huang et al. (Ref 19) for Sn-9Zn- $x \mathrm{Cu}$ alloys $(x=0.5-3.0 \mathrm{Cu}) \mathrm{Cu}_{5} \mathrm{Zn}_{8}$ is the primary crystallizing phase. Although the $\mathrm{CuZn}_{4}$ precipitates seem to be concentrated in the vicinity of interface they are randomly distributed in the solder. If the samples were kept in liquid for a long time sedimentation would be observed due to a density difference between precipitates (for instance, $\mathrm{Cu}_{5} \mathrm{Zn}_{8}$ is $\sim 8.0 \mathrm{~g} / \mathrm{cm}^{3}$ ) and the solder matrix $\left(\sim 7.0 \mathrm{~g} / \mathrm{cm}^{3}\right)$ as explained by Song (Ref 15). Song (Ref 15) studied sedimentation behavior of $\mathrm{Cu}-\mathrm{Zn}$ precipitates in the above-mentioned solders held at $250{ }^{\circ} \mathrm{C}$ for $20 \mathrm{~min}$. Since the temperatures at which the intermetallics from 


\begin{tabular}{|c|c|c|c|c|c|}
\hline \multirow[b]{2}{*}{ t (s) } & \multicolumn{3}{|c|}{ Composition (at\%) } & \multirow[b]{2}{*}{ Phase } & \multirow[b]{2}{*}{ Figure no. } \\
\hline & Sn & $\mathrm{Cu}$ & Zn & & \\
\hline \multicolumn{6}{|c|}{$\mathrm{Sn}-\mathrm{Zn}-0.5 \mathrm{Cu}$} \\
\hline 15 & 10.0 & 22.1 & 67.8 & $\varepsilon-\mathrm{CuZn} \mathrm{n}_{4}$ & \\
\hline 30 & 5.6 & 22.0 & 72.4 & $\varepsilon-\mathrm{CuZn} 4$ & \\
\hline $60(\#)$ & 4.6 & 22.2 & 73.2 & $\varepsilon-\mathrm{CuZn} \mathrm{n}_{4}$ & \\
\hline 60 & & 35.4 & 64.6 & $\gamma-\mathrm{Cu}_{5} \mathrm{Zn}_{8}$ & \\
\hline $180(\#)$ & 3.3 & 21.3 & 75.4 & $\varepsilon-\mathrm{CuZn}{ }_{4}$ & \\
\hline 180 & 0.2 & 35.1 & 64.7 & $\gamma-\mathrm{Cu}_{5} \mathrm{Zn}_{8}$ & \\
\hline \multicolumn{6}{|c|}{$\mathrm{Sn}-\mathrm{Zn}-1.0 \mathrm{Cu}$} \\
\hline 15 & 9.5 & 27.0 & 63.5 & $\varepsilon-\mathrm{CuZn} \mathrm{n}_{4}$ & 2(a) \\
\hline 30 & 9.7 & 21.7 & 68.5 & $\varepsilon-\mathrm{CuZn} \mathrm{n}_{4}$ & $2(b)$ \\
\hline $60(\#)$ & 10.5 & 24.1 & 65.4 & $\varepsilon-\mathrm{CuZn}_{4}$ & $2(\mathrm{c})$ \\
\hline 60 & 2.5 & 42.8 & 54.7 & $\gamma-\mathrm{Cu}_{5} \mathrm{Zn}_{8}$ & $2(\mathrm{c})$ \\
\hline $180(\#)$ & 2.6 & 24.5 & 72.9 & $\varepsilon-\mathrm{CuZn} \mathrm{n}_{4}$ & $2(d)$ \\
\hline 180 & 0.9 & 34.2 & 64.9 & $\gamma-\mathrm{Cu}_{5} \mathrm{Zn}_{8}$ & $2(d)$ \\
\hline \multicolumn{6}{|c|}{$\mathrm{Sn}-\mathrm{Zn}-1.5 \mathrm{Cu}$} \\
\hline 15 & 8.3 & 20.6 & 71.0 & $\varepsilon-\mathrm{CuZn} \mathrm{n}_{4}$ & \\
\hline 30 & 5.3 & 19.5 & 75.2 & $\varepsilon-\mathrm{CuZn}_{4}$ & \\
\hline $60(\#)$ & 4.2 & 23.0 & 72.8 & $\varepsilon-\mathrm{CuZn}_{4}$ & \\
\hline 60 & 0.5 & 36.1 & 63.3 & $\gamma-\mathrm{Cu}_{5} \mathrm{Zn}_{8}$ & \\
\hline $180(\#)$ & 3.2 & 23.7 & 73.1 & $\varepsilon-\mathrm{CuZn} \mathrm{n}_{4}$ & \\
\hline 180 & & 35.1 & 64.9 & $\gamma-\mathrm{Cu}_{5} \mathrm{Zn}_{8}$ & \\
\hline (\#) Upper & & & & & \\
\hline
\end{tabular}

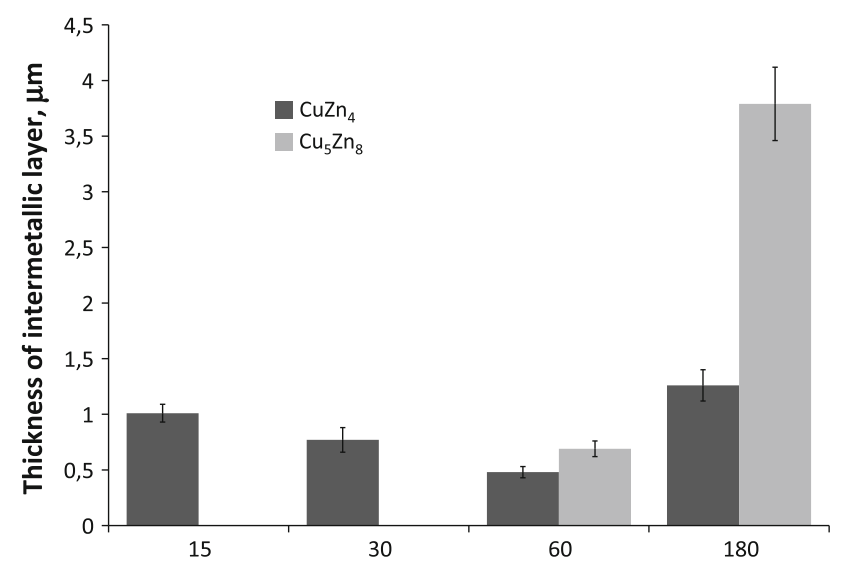

Fig. 5 Thickness of the interlayer at $250{ }^{\circ} \mathrm{C}$ at the $\mathrm{Sn}-\mathrm{Zn}-1.0 \mathrm{Cu} / \mathrm{Cu}$ interface

$\mathrm{Cu}-\mathrm{Zn}$ crystallize are much higher than $300{ }^{\circ} \mathrm{C}$, it was assumed (Ref 15 ) that at $250{ }^{\circ} \mathrm{C}$ the originally precipitated "as-cast" IMPs would sediment. They observed both $\mathrm{CuZn}_{4}$ and $\mathrm{Cu}_{5} \mathrm{Zn}_{8}$ in the $\mathrm{SnZn}-0.5 \mathrm{Cu}$ solder but only $\mathrm{Cu}_{5} \mathrm{Zn}_{8}$ in solders containing $\geq 1$ wt. $\% \mathrm{Cu}$. In their experiment they found that the "as-cast" IMPs dissolve into Sn-Zn matrix at $250{ }^{\circ} \mathrm{C}$ and precipitate again. After $20 \mathrm{~min}$ of holding at $250{ }^{\circ} \mathrm{C}$ they found rounded precipitates of $\varepsilon-\mathrm{CuZn}{ }_{4}$ which sediment in 0.5 and $1.0 \mathrm{wt} \%$ $\mathrm{Cu}$ samples, and dendritic precipitates of $\mathrm{Cu}_{5} \mathrm{Zn}_{8}$ randomly distributed in Sn-9Zn matrix. They explained this dissolutionprecipitation behavior by high solubility of $\mathrm{Zn}$ in liquid $\mathrm{Sn}$.

\subsection{Al Substrate}

The wetting angles of $\mathrm{Sn}-\mathrm{Zn}-1.0 \mathrm{Cu}$ on $\mathrm{Al}$, shown in Fig. 7, are much lower than the wetting angle of the respective alloy on (a) substrate

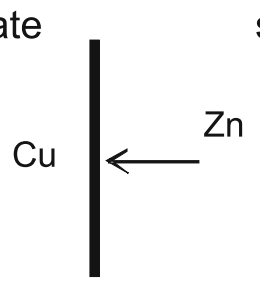

solder

(b)

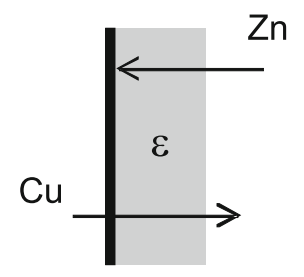

(c)

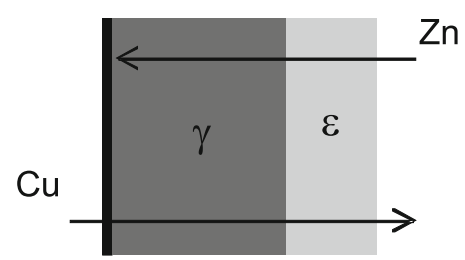

Fig. 6 Sequence of growth of IMC at the $\mathrm{Sn}-\mathrm{Zn}-x \mathrm{Cu} / \mathrm{Cu}$ interface ( $x$ up to $1.5 \mathrm{wt} . \%$ ) at the early stage of liquid-solid interaction. Sketch is not in scale

$\mathrm{Cu}$. Considering wetting of $\mathrm{Sn}-\mathrm{Zn}-1.0 \mathrm{Cu}$ on $\mathrm{Al}$ substrate, the present data are close to those of $\mathrm{Sn}-8.8 \mathrm{Zn}$ and $\mathrm{Sn}-\mathrm{Zn}-\mathrm{In}$ reported earlier on the same type of substrate and in the 


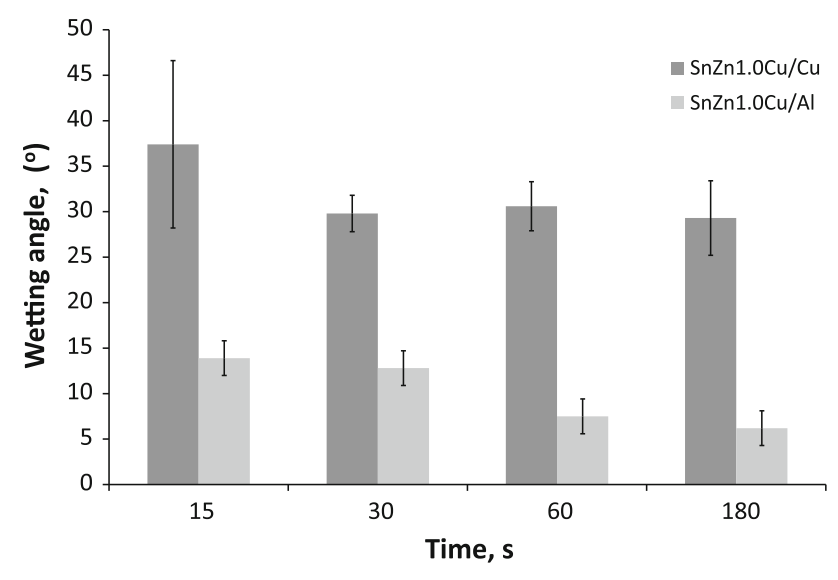

Fig. 7 Wetting angles of $\mathrm{Sn}-\mathrm{Zn}-1.0 \mathrm{Cu}$ alloy on $\mathrm{Cu}$ and $\mathrm{Al}$ pads
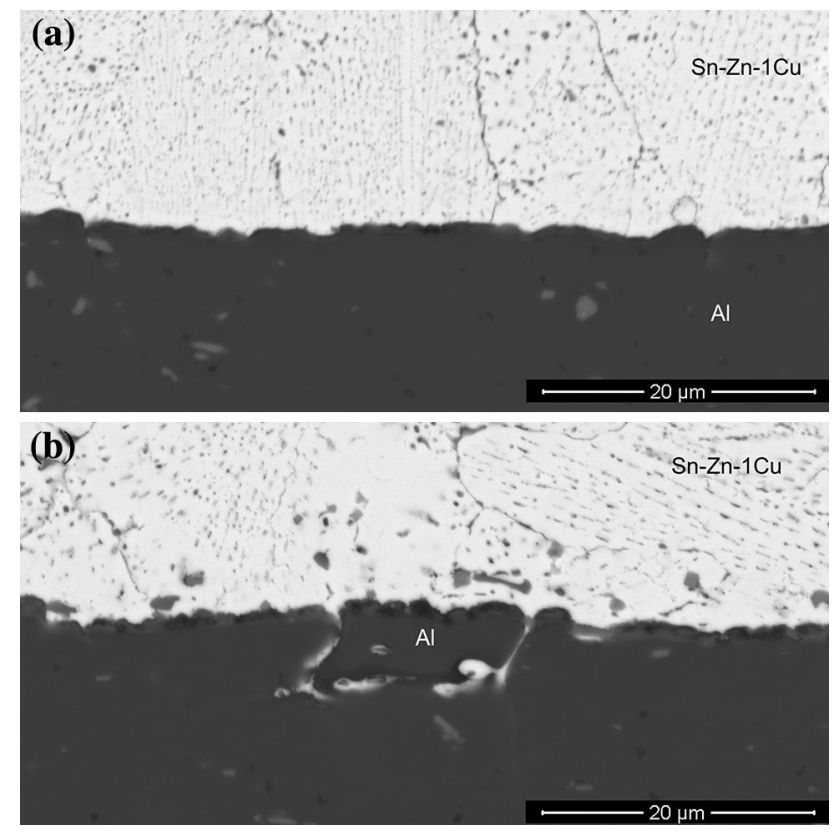

Fig. 8 Interfacial microstructure of $\mathrm{Sn}-\mathrm{Zn}-1.0 \mathrm{Cu} / \mathrm{Al}$ couples after wetting time of (a) 15 and (b) $180 \mathrm{~s}$

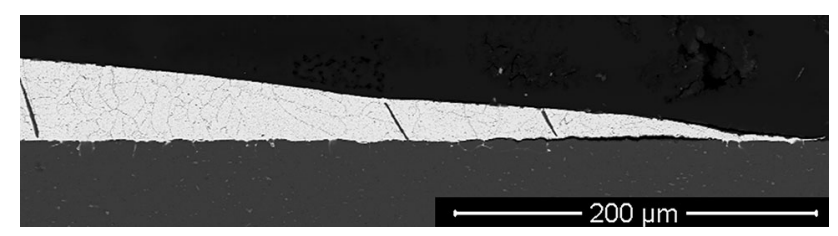

Fig. $9 \mathrm{Sn}-\mathrm{Zn}-1.0 \mathrm{Cu} / \mathrm{Al}$ interface after $180 \mathrm{~s}$ of wetting at $250{ }^{\circ} \mathrm{C}$

presence of the same flux, but longer time of wetting (Ref 20). Figure 8(a) and (b) illustrates interfacial microstructure of Sn$\mathrm{Zn}-1.0 \mathrm{Cu} / \mathrm{Al}$ couples after 15 and $180 \mathrm{~s}$ of wetting, respectively. One could see that the interface is much different than in the case of $\mathrm{Sn}-\mathrm{Zn}-\mathrm{Cu} / \mathrm{Cu}$ couples, i.e., no interlayer is observed at solder/substrate interface in agreement with Al-Sn and Al-Zn phase diagrams.
The interface between $\mathrm{Sn}-\mathrm{Zn}-1.0 \mathrm{Cu}$ solder alloy and $\mathrm{Al}$ substrate is rather rough and the substrate roughness increases with increasing time of wetting. This system is an example of dissolutive wetting, theory and examples of which can be found in review (Ref 21). It is observed that at $180 \mathrm{~s}$, solder grooves and penetrates the substrate along grain boundaries leading to some grains being separated, at least partially, from the surrounding substrate. This kind of dissolution of substrate may lead to Al grains detached and floating near the substrate as shown in Ref 11,22 . The $\mathrm{Sn}-\mathrm{Zn}-1.0 \mathrm{Cu} / \mathrm{Al}$ interface after $180 \mathrm{~s}$ of wetting resemble the $\mathrm{Sn}-\mathrm{Zn} / \mathrm{Al}$ and $\mathrm{Sn}-\mathrm{Zn}-\mathrm{In} / \mathrm{Al}$ interfaces after $300 \mathrm{~s}$ of wetting and more, discussed in our earlier work (Ref 20, 22). The EDS analysis performed near the interface confirmed that $\mathrm{Al}$ dissolved in $\mathrm{Sn}-\mathrm{Zn}-1.0 \mathrm{Cu}$ alloy. Nevertheless, as pointed before, one has to be cautious regarding the EDS results because of small size of microstructure features and the associated errors of measurement. Figure 9 shows the $\mathrm{Sn}-\mathrm{Zn}-1.0 \mathrm{Cu} / \mathrm{Al}$ couple after $180 \mathrm{~s}$ at $250^{\circ} \mathrm{C}$. No significant dissolution of the substrate, except for grooves, can be observed. This and the fact that the wetting angle after $180 \mathrm{~s}$ is close to that after $15 \mathrm{~s}$ is an indication that dissolution kinetics is much slower than the kinetics of wetting.

\section{Conclusion}

The study of microstructure evolution of the interface between $\mathrm{Sn}-\mathrm{Zn}-\mathrm{xCu}$ alloys on $\mathrm{Cu}$ and $\mathrm{Al}$ substrates was performed with the sessile drop method. It was found that $\mathrm{Sn}$ $\mathrm{Zn}-x \mathrm{Cu} / \mathrm{Al}$ interface is different from $\mathrm{Sn}-\mathrm{Zn}-x \mathrm{Cu} / \mathrm{Cu}$. In the first case there are no reaction products at the interface but the alloy dissolves the substrate along grain boundaries similar to $\mathrm{Sn}-\mathrm{Zn}$ alloys reported earlier. In the case of copper, substrate formation of intermetallic interlayers is observed. Initially (15 and $30 \mathrm{~s}$ ) only single layer is present with the composition close to $\mathrm{CuZn}_{4}$. After a long time (60 and $180 \mathrm{~s}$ ) two interlayers can be distinguished at the interface one $\mathrm{Cu}_{5} \mathrm{Zn}_{8}$ adjacent to the substrate, and the other $\mathrm{CuZn}_{4}$ adjacent to $\mathrm{SnZnCu}$ alloy. The thickness of the $\mathrm{CuZn}_{4}$ remains small during the experiment while the thickness of $\mathrm{Cu}_{5} \mathrm{Zn}_{8}$ increases as observed in the literature.

\section{Acknowledgment}

This work was financed under the framework of the project POIG.01.01.02-00-015/09, co-funded by the European Regional Development Fund (ERDF) and the Government of Poland under the Innovative Economy Program in the years 2010-2013.

\section{Open Access}

This article is distributed under the terms of the Creative Commons Attribution License which permits any use, distribution, and reproduction in any medium, provided the original author(s) and the source are credited.

\section{References}

1. L.R. Garcia, W.R. Osório, L.C. Peixoto, and A. Garcia, Wetting Behavior and Mechanical Properties of $\mathrm{Sn}-\mathrm{Zn}$ and $\mathrm{Sn}-\mathrm{Pb}$ Solder Alloys, J. Electron. Mater., 2009, 38(11), p 2405-2414 
2. J. Jiang, J.-E. Lee, K.-S. Kim, and K. Suganuma, Oxidation Behavior of Sn-Zn Solders Under High-Temperature and High-Humidity Conditions, J. Alloy. Compd., 2008, 462, p 244-251

3. J.H. Vincent, B.P. Richards et al., Alternative Solders for Electronics Assemblies: Part 2: UK Progress and Preliminary Trials, Circuit World, 1993, 19, p 32-34

4. K.-L. Lin and C.-L. Shih, Microstructure and Thermal Behavior of SnZn-Ag Solders, J. Electron. Mater., 2003, 32(12), p 1496-1500

5. K.-L. Lin and C.-L. Shih, Wetting Interaction between Sn-Zn-Ag Solders and Cu, J. Electron. Mater, 2003, 32(2), p 95-100

6. K. Bukat, J. Sitek, M. Koscielski, Z. Moser, W. Gasior, and J. Pstrus, Investigation of Sn-Zn-Bi Solders: Part II: Wetting Measurements on Sn-Zn7Bi Solders on Copper and on PCBs with Lead-Free Finishes by Means of the Wetting Balance Method, Solder. Surf. Mt. Technol., 2010, 22(4), p 13-19. doi:10.1108/09540911011076844

7. S. Chou, S. Chen, and Y. Chang, Interfacial Reactions in the Sn-9Zn$(x \mathrm{Cu}) / \mathrm{Cu}$ and $\mathrm{Sn}-9 \mathrm{Zn}-(x \mathrm{Cu}) / \mathrm{Ni}$ couples, J. Mater. Res., 2006, 21, $\mathrm{p}$ 1849-1856

8. S.-P. Yu, C.-L. Liao, M.-H. Hon, and M.-C. Wang, The Effect of Flux on the Wetting Characteristics of Near-Eutectic Sn-Zn-In Solder on $\mathrm{Cu}$ Substrate, J. Mater. Sci., 2000, 35, p 4217-4224

9. L. Zhang, S. Xue, L. Gao, Z. Sheng, H. Ye, Z. Xiao, G. Zeng, S. Yu, Y. Chen, and S. Yu, Development of Sn-Zn Lead-Free Solders Bearing Alloying Elements, J. Mater. Sci., 2010, 21, p 1-15

10. M. Maeda, S. Kitamori, and Y. Takahashi, Interfacial Microstructure Between Thick Aluminium Wires and Aluminium Alloy Pads Formed by Ultrasonic Bonding, Sci. Technol. Weld. Join., 2013, 18(2), p 103107

11. M.I. Huang, Y.Z. Huang, H.T. Ma, and J. Zhao, Mechanical Properties and Electrochemical Corrosion Behavior of $\mathrm{Al} / \mathrm{Sn}-9 \mathrm{Zn}-x \mathrm{Ag} / \mathrm{Cu}$ Joints, J. Electron. Mater, 2011, 40, p 315
12. D.Q. Yu, H.P. Xie, and L. Wang, Investigation of Interfacial Microstructure and Wetting Property of Newly Developed $\mathrm{Sn}-\mathrm{Zn}-\mathrm{Cu}$ Solders with Cu Substrate, J. Alloy. Compd., 2004, 385, p 119-125. doi:10.1016/j.jallcom.2004.04.129

13. P. Fima, T. Gancarz, J. Pstrus, and A. Sypien, Wetting of Sn-Zn-xIn $(x=0.5,1.0,1.5$ wt.\%) Alloys on $\mathrm{Cu}$ and Ni Substrates, J. Mater. Eng. Perform., 2012, 21, p 595-598

14. O. Dezellus and N. Eustathopoulos, Fundamental Issues of Reactive Wetting by Liquid Metals, J. Mater. Sci., 2010, 45, p 4256-4264. doi: 10.1007/s10853-009-4128-x

15. J.M. Song, Sedimentation of $\mathrm{Cu}$-Rich Intermetallics in Liquid LeadFree Solders, J. Mater. Res., 2007, 22(12), p 4332-4339

16. C.S. Lee and F.S. Shieu, Growth of Intermetallic Compounds in the Sn9Zn/Cu Joint, J. Electron. Mater., 2006, 35(8), p 1660-1664

17. B.J. Lee, N.M. Hwang, and H.M. Lee, Prediction of Interface Products Between $\mathrm{Cu}$ and Various Solder Alloys by Thermodynamic Calculations, Acta Mater., 1997, 45(5), p 1867-1874

18. Q. Lai, N. Zhang, and N. Eustathopoulos, Enhanced Wetting of DualPhase Metallic Solids by Liquid Metals: A New Effect of Interfacial Reaction, Acta Mater, 2013, 61, p 4127-4134

19. Y.-C. Huang, S.-W. Chen, C.-Y. Chou, and W. Gierlotka, Liquidus Projection and Thermodynamic Modeling of Sn-Zn-Cu Ternary System, J. Alloy. Compd., 2009, 477, p 283-290. doi:10.1016/j.jallcom.2008.10.156

20. P. Fima, K. Berent, J. Pstruś, and T. Gancarz, Wetting of Al Pads by Sn-8.8Zn and Sn-8.7Zn-1.5(Ag, In) Alloys, J. Mater. Sci., 2012, 24, p 8472-8476. doi:10.1007/s10853-012-6777-4

21. T.J. Singler, S. Su, L. Yin, and B.T. Murray, Modeling and Experiments in Dissolutive Wetting: A Review, J. Mater. Sci., 2012, 47, p 82618274. doi:10.1007/s10853-012-6622-9

22. J. Pstrus, P. Fima, and T. Gancarz, Wetting of $\mathrm{Cu}$ and $\mathrm{Al}$ by $\mathrm{Sn}-\mathrm{Zn}$ and Zn-Al Eutectic Alloys, J. Mater. Eng. Perform., 2012, 21, p 606-613 